\title{
IS SECTION 1981 MODIFIED BY TITLE VII OF THE CIVIL RIGHTS ACT OF 1964?
}

In the past several years both the courts and the Congress have become more involved in the black American's struggle for equality. As part of this increased involvement, Congress passed the first extensive civil rights legislation ${ }^{1}$ in nearly one hundred years, and the Supreme Court revitalized a major portion of Reconstruction legislation. In Jones v. Alfred $H$ Mayer Co., ${ }^{2}$ the Court held that section 1982 of title 42, a provision from the Civil Rights Act of $1866,{ }^{3}$ bars racial discrimination in the rental or sale of housing by private parties. ${ }^{4}$ The Court further found that the Fair Housing Title of the Civil Rights Act of 1968 did not repeal or otherwise affect the vitality of section $1982 .{ }^{5}$ Interpreting section 1981 of title 42, apparently derived from the 1866 Act, the Court of Appeals for the Seventh Circuit in Waters v. Wisconsin Steel Works ${ }^{7}$ held that although section 1981 prohibits private discrimination in employment, it is modified by the Fair Employment Title of the Civil Rights Act of 1964. This note will examine the justification for. holding that section 1981 has been modified by the 1964 Civil Rights Act, while section 1982 has been held to be unaffected by similar civil rights legislation.

\section{Civil Rights Act of 1866}

\section{Historical Background}

Although President Lincoln said that the Civil War was a struggle to preserve the Federal Union rather than an attempt to abolish slavery, ${ }^{8}$ clearly, the "fate of slavery was inextricably linked to the outcome of the war." The pressure upon Lincoln to make the

1. Civil Rights Act of 1968, 42 U.S.C. $\$ 3601$ et seq. (Supp. V, 1970); Civil Rights Act of 1964,42 U.S.C. $\S 2000 \mathrm{a}$ et seq. (1964).

2. 392 U.S. 409 (1968).

3. 42 U.S.C. $\S 1982$ (1964). See note 26 infra and accompanying text.

4. 392 U.S. at 421 . Some commentators have disagreed strongly with the Court's reasoning in Jones, See, e.g., Casper, Jones v. Mayer: Clio Bemused and Confused Muse, 1968 S. CT. Rev. 89; The Supreme Court, 1967 Term, 82 HaRv. L. Rev. 63, 95-103 (1968).

5. 392 U.S. at $416-17$.

6. See notes 82-86 infra and accompanying text.

7. 427 F.2d 476, 487 (7th Cir.), cert. denied, 39 U.S.L.W. 3200 (U.S. Nov. 9, 1970).

8. Letter from Abraham Lincoln to Horace Greeley, Aug. 22, 1862 [published in N.Y. Tribune, Aug. 25, 1862].

9. See Kohl, The Civil Rights Act of 1866, Its Hour Come Round at Last. 55 VA. L. REv. 
abolition of slavery the principal issue of the war resulted, to some extent, in his issuance of the Emancipation Proclamation in September of $1862 .{ }^{10}$ The Proclamation declared that slaves in the seccessionist states would be "forever free."11

Once military victory was assured to the Union forces, doubts arose concerning the viability of emancipation following the end of hostilities. Congressional Republicans felt that action on their part was necessary to assure a lasting abolition of slavery, and with this consideration the thirteenth amendment was added to the Constitution. ${ }^{12}$ The thirteenth amendment provides that "[n]either slavery nor involuntary servitude . . . shall exist . . . ."13 and grants to Congress the power to enforce this provision by appropriate legislation. Because of the obscurity of the origin of slavery and the probability that the institution resulted from tradition and custom, rather than specific legal provisions, the first section of the thirteenth amendment prohibits the existence of slavery itself rather than the laws which supported it. ${ }^{14}$

After the conclusion of the Civil War, Congress, convinced that black people were not actually enjoying equal rights under state reconstruction governments, ${ }^{15}$ enacted a panoply of civil rights legislation directed toward the permanent abolition of slavery and all the incidents thereof. ${ }^{16}$ The first act of the 39th Congress was to

272, 273 (1969) [hereinafter cited as Kohl]. See generally J. McPherson, THE StrUGGLE FOR EQUALTTY 99-133 (1964).

10. Kohl 273.

11. T. Williams, abraham lincoln: Selected Speeches, Messages, and Letters 211 (1957). The Proclamation was to take effect Jan. 1, 1863. Id.

12. Kohl 273. The debate in Congress on the thirteenth amendment began in mid-March of 1864 and ended with the formal proposal of the amendment on January 31, 1865, just three months before the surrender of General Lee at Appomattox. See generally CONG. GLOBE, 38th Cong., 1st Sess. 1199 (1864), through Cong. GzoBE, 38th Cong., 2d Sess. 531 (1865).

13. U.S. ConsT. amend. XI11.

14. Kohl 279. See, e.g., Wainwright v. Bridges, 19 La. Ann. 234, 237 (1867), asserling that "[S]lavery was never, strictly speaking, established in this country by positive law." See also 1 J. HURD, THe LAW OF FREEDOM AND BONDAGE IN THE UNited StaTES 577 (1858), where it was said: "[P]roperty in slaves does not rest upon positive statute, but upon unwritten law. . . ."

15. Kohl 279.

16. Act of April 9, 1866, ch. 31, 14 Stat. 27; Act of May 31, 1870, ch. 114, 16 Stat. 140; Act of Feb. 28, 1871, ch. 99, 16 Stat. 433; Act of March 1, 1875, ch. 114, 18 Stat. 335. The full text of this legislation can be found in R. CARR, Federal Protection of Civil Rights: QUeSt for A SwORD 211-49 (1947). For the details of what happened to these acts, see, e.g.. Substantive Civil Rights Under Federal Legislation, 3 RACE REL. L. REP. 133-61 (1958); Gressman, The Unhappy History of Civil Rights Legislation, 50 Mich. L. REv. 1323 (1952); Maslow \& Robison, Civil Rights Legislation and the Fight for Equality 1869-1952, 20 U. CHI. L. REv. 363 (1953). 
appoint a Joint Committee of Fifteen to "inquire into the condition of the [seccessionist] States." 17 Not until the Committee had submitted its report were representatives from the southern states to be seated in Congress. ${ }^{18}$

The findings and conclusions of the Committee, issued in early 1866, are highly germane to the determination of the evils which the 1866 Civil Rights Act was intended to remedy. While the South was removing the legal disabilities of slavery, it was covertly undertaking to reintroduce a new, privately enforced slave system. ${ }^{19}$ The Committee carefully inquired of the many witnesses testifying before it whether the freedman was, in fact, able to contract out his labor in a free market and whether the southern white landowner would actually sell property to blacks. ${ }^{20}$ Although the Black Codes did not prohibit Negro access to the land and labor markets, the Committee found that access was extremely limited in practice. With respect to labor, it found that some whites physically coerced freedmen into signing employment contracts at substantially lower wages than those paid to whites. ${ }^{21}$ These attempts by white southerners to deny the black man

17. Report of the Joint Committee on Reconstruction, 39th Cong., ist Sess. at VII (1866) [hereinafter cited as REPORT].

18. Id.

19. Kohl 279-80. See, e.g., letter of Col. Samuel Thomas, Asst. Commissioner for Mississippi and N.E. Louisiana, S. ExEc. Doc. No. 2, 39th Cong., Ist Sess. at 82 (1865). Col.

Thomas wrote:

All the trickery, chicanery and political power possible are being brought to bear on the poor negro, to make him do the hard labor for the whites, as in the days of old.

To this end the mass of people are instinctively working. They steadily refuse to sell or lease lands to black men. Colored mechanics of this city, who have made several thousand dollars during the last two years, find it impossible to buy even land enough to put up a house on, yet white men can purchase any amount of land. The whites know that if negroes are not allowed to acquire property or become landowners, they must ultimately return to plantation labor, and work for wages that will barely support themselves and families, and they feel that this kind of slavery will be better than none at all.

20. See REPORT VII.

21. REPORT 11-55, 11-83. Wage fixing was so prevalent that General Terry ordered nonenforcement of the Vagrant Act because:

In many counties of this State meetings of employers have been held, and unjust and wrongful combinations have been entered into for the purpose of depressing the wages of the freedmen below the real value of their labor, far below the prices formerly paid to masters for labor performed by their slaves. . . . The effect of the statute in question will be, therefore, to compel the freedmen, under penalty of punishment as criminals, to accept and labor for the wages established by these combinations of employers. $E$. McPherson, Polttical Mañual For 1866 at 42 (1866). 
his newly acquired rights demonstrated that the laissez faire approach of Congress toward the freedman was a failure. ${ }^{22}$

\section{Provisions of the Act}

To the 39th Congress, dominated by Radical Republicans, this circumvention of the thirteenth amendment and denial of the newly won rights of Negroes was intolerable. The Radicals reacted by commencing Reconstruction with a vengeance, ${ }^{23}$ and the result was the Civil Rights Act of 1866. In light of the facts brought to the attention of Congress by the Committee of Fiftcen and the radical temper of the 39th Congress, it does not seem surprising that Congress would enact legislation intending to prohibit all racially motivated discrimination, public and private.

Section 1 of the Civil Rights Act of 1866 provided:

Be it enacted . . . that all persons born in the United States . . . are hereby declared to be citizens of the United States; and such citizens of every race and color, without regard to any previous condition of slavery or involuntary servitude ... shall have the same right, in every state and territory in the United States, to make and enforce contracts, to sue, be parties, and give evidence, to inherit, purchase, lease, sell, hold, and convey real and personal property, and to full and equal benefit of all laws and proceedings for the security of person and property, as is enjoyed by white citizens . . . .24

Section 1 was re-enacted in 1870 after ratification of the fourteenth amendment and is apparently codified in two sections of title $42 .{ }^{25}$ Section 1982, apphed by the Supreme Court in Jones, provides:

All citizens of the United States shall have the same right, in every State and Territory, as is enjoyed by white citizens thereof, to inherit, purchase, lease, sell, hold, and convey real and personal property. 26

Its companion statute, section 1981 , provides:

All persons within the jurisdiction of the United States shall have the same right in every State . . . to make and enforce contracts . . . as is enjoyed by white citizens . . . .

22. See Jones v. Alfred H. Mayer Co., 392 U.S. 409, 449-80 (1968) (Harlan, J., dissenting).

23. Kohl 283.

24. Act of April 9, 1866, ch. 31, § 1, 14 Stat. 27.

25. See 392 U.S. at 442 n. 28; Young v. International Tel. \& Tcl. Co., 39 U.S.L.W. 2489 (3rd Cir. Feb. 11, 1971); Boudreaux v. Baton Rouge Marine Contracting Co., - F.2d - (5th Cir. 1971). But see Cook v. The Advertising Co., 39 U.S.L.W. 2413 (M.D. Ala. Jan. 15, 1971).

26. 42 U.S.C. $\S 1982$ (1964).

27. Id. § 1981 . 


\section{Interpretation}

In Jones v. Alfred H. Mayer Co., ${ }^{28}$ where the company refused to sell a house to Jones because he was a Negro, the Supreme Court held that section 1982 prohibits racial discrimination in the rental and sale of housing by private parties. Based on Jones, it has been contended that section 1981 is as applicable to private racial discrimination in employment as section 1982 is applicable to such discrimination in housing. ${ }^{29}$ The validity of this theory has been litigated several times with conflicting results. ${ }^{30}$ Most of the fundamental arguments against the utilization of section 1981 against racial employment discrimination are found in Harrison v. American Can $\mathrm{Co}^{31}$ In that case the district court suggested that it does not necessarily follow from Jones that section 1981 applies to private racial discrimination in employment since section 198I was not intended to reach private conduct, as was section 1982. Reference to the Jones decision appears to dispell this notion, for in that case the Court emphasized that "the structure of the 1866 Act as well as its language, points to the conclusion ... that $\S 1$ [from which both sections 1981 and 1982 were apparently derived] was meant to prohibit all racially motivated deprivations of the rights enumerated in the statute." 32

The Harrison court also contended that the words "to make and enforce contracts" in section 1981 do not clearly relate to employment, while the language of section 1982 plainly applied to the

28. 392 U.S. 409 (1968).

29. See Note, Racial Discrimination in Employment Under the Civil Rights Act of 1866, 36 U. CHI. L. Rev. 616 (1969). See generally Larson, The New Law of Race Relations, 1969 WISC. L. REv. 470.

30. For those cases in which this theory was opposed, see, e.g., Harrison v. American Can Co., 2 F.E.P. Cases 1 (S.D. Ala. 1969); Colbert v. H-K Corp., 295 F. Supp. 1091 (N.D. Ga. 1968); Kendrick v. American Bakery Co., I F.E.P. Cases 349 (N.D. Ga. 1968); Norman v. Missouri Pacific R.R., I F.E.P. Cases 331 (E.D. Ark. 1968), vacated and remanded, 414 F.2d 73 (8th Cir. 1969). All but the Harrison case rejected the 1981 claim because there was no state action involved and no consideration was given to the possible ramifications of the Jones $v$. Mayer decision. Cases in which the application of section 1981 was favored include Waters v. Wisconsin Steel Works, 427 F.2d 476 (7th Cir.) cert. denied, 39 U.S.L.W. 3200 (Nov. 9, 1970); Clark v. American Marine Corp., 304 F. Supp. 603 (E.D. La. 1969) (dictum); Dobbins v. Local 212, lBEW, 292 F. Supp. 413 (S.D. Ohio 1968).

31. 2 F.E.P. Cases I (S.D. Ala. 1969). See notes $82-86$ infra, and accompanying text.

32. 392 U.S. at 426. See Waters v. Wisconsin Steel Works, 422 F.2d 426, 482 (7th Cir. 1970). But see Cook v. The Advertiser Co., 39 U.S.L.W. 2413 (M.D. Ala. Jan. 15, 1971). 
activity involved in Jones. However, as Mr. Justice Stewart, speaking for the Court, pointed out in Jones:

The Congressional debates are replete with references to private injustices against Negroes-references to White employers wbo refused to pay their Negro workers, White planters who agreed among themselves not to hire freed slaves without the permission of their former masters . . . .3

Thus, it is apparent from the legislative history of the 1866 Act that Congress sought to prohibit all racial discrimination whether or not under color of law and that discrimination in employment was clearly one of the evils Congress sought to correct. Moreover, the Court in Jones $^{34}$ expressly overruled Hodges $v$. United States ${ }^{35}$ which had indicated that section 1981 did not apply to a conspiracy by private individuals to interfere with a contract for employment.

\section{Civil Rights Act of 1964}

Four years before Jones and apparently without the knowledge that section 1981 might be utilized to prevent private discrimination in employment, ${ }^{36}$ Title VII of the Civil Rights Act of 1964 was enacted. Title VII was an attempt by Congress to deal comprehensively with problems of equal employment opportunity. ${ }^{37}$ It was passed only after an arduous struggle against, and eventual compromise with, powerful conservative forces in Congress who succeeded in almost completely abrogating the strong enforcement provisions originally proposed. ${ }^{38}$ The Title applies to employers in an

33. 392 U.S. at 427. See Waters v. Wisconsin Steel Works, 427 F.2d 476 (7th Cir. 1970); Cong. Globe, 39th Cong., Ist Sess. 1160,1833 (1860). See also 82 HaRv. L. Rev., supra note 4 , at 103 n.31.

34. 392 U.S. at $441-42$ n.78.

35. 203 U.S. 1 (1906). In Hodges a group of white men had terrorized several Negroes to prevent them from working in a sawmill. The terrorizers were convicted under 18 U.S.C. $\S 241$ (1964), of conspiring to prevent the Negroes from exercising the right to contract for employment, a right secured to them by section 1981. The Supreme Court reversed the conviction holding that only conduct which actually enslaves someone can be subjected to punishment under legislation ehacted to enforce the thirteenth amendment. Said the Jones court: "The conclusion of the majority in Hodges rested upon a coneept of congressional power under the thirteenth amendment irreeoncilable . . . and incompatible with the history and purpose of the amendment itself." 392 U.S. at $441-43$ n.78.

36. The Civil Rights Act of 1866 was never mentioned in either the debates or committee hearings concerning Title VIl.

37. See, e.g., Vass, Title VII: Legislative History, 7 B.C. IND. AND CoM. L. Rev. 431 (1966).

38. Id. In the House of Representatives for example, the bill was debated for 64 hours. 155 amendments were offered, and 34 were approved. Indeed, the Senate legislative deadlock precipitated by the bill required the use of cloture to cut off dehate-for only the [second time in history]. 110 Cong. ReC. 12860 (1964).

As originally drafted, Title VII was to have been admimistered by a federal agency empowered 
industry affecting interstate commerce which have 25 or more employees; ${ }^{39}$ employment agencies, labor unions, and joint labormanagement committees which control apprenticeship and other training programs are also covered. ${ }^{40}$ The statute is aimed at employment discrimination based not only on race or color, but also on sex, religion, or national origin.

Title Vll, with strong emphasis on conciliation, created the Equal Employment Opportunity Commission (EEOC). This Commission has the responsibility for receiving and investigating complaints filed by "aggrieved persons" and attempting by means of "conference and conciliation" to eliminate unlawful employment practices when it determines that "reasonable cause" exists to believe that there has been a violation of the Title. ${ }^{41}$ Commission members have the power to initiate unfair employment investigations whenever they have reason to believe that the Act has been violated. ${ }^{42}$ If conciliation attempts by the Commission are to no avail, enforcement devolves to the aggrieved party who is then required to file a civil suit within 30 days or risk forfeiture of Title VII remedies. ${ }^{43}$ The Attorney General of the United States also has the right to commence a suit on his own initiative, if he has "reasonable cause to believe that any person or groups of persons are engaged in a pattern or practice of resistance" that would impair the full enjoyment of the rights enumerated in the Title. ${ }^{44}$ The Title also allows the Attorney General to intervene in private civil actions when he certifies that the case is of general public importance. ${ }^{45}$

In summary, the statute provides three primary methods for enforcement: conciliation by the EEOC; judicial enforcement through private civil actions after conciliation has failed; and judicial

to eliminate discriminatory practices by cease and desist orders. See Berg, Equal Employment Opportunity Under the Civil Rights Act of 1964, 31 BrookLyN L. REv. 62, 64-68 (1964). Due to the strenuous opposition of many congressmen, the agency was stripped of its coercive powers and relegated to the role of a mediator. Comment, The Civil Rights Act of 1964: Racial Discrimination By Labor Unions, 41 ST. Johns L. Rev. 58, 61 (1966). See also 110 Cong. Rec. 13693 (1964).

39. 42 U.S.C. $\S 2000 \mathrm{e}(\mathrm{b})(1964)$.

40. Id. $\$ 2000 \mathrm{e}(\mathrm{c})(\mathrm{e})$.

41. Id. $\S 2000 \mathrm{e}-5(\mathrm{a})$.

42. Id.

43. Id. See Coleman, Title VII of the Civil Rights Act: Four Years of Procedural Elucidation, 8 DuQ. L. REv. 1 (1970).

44. 42 U.S.C. $\S 2000 e-6$ (a) (1964).

45. Id. $\$ 2000 \mathrm{e}-5(\mathrm{e})$. 
enforcement through "pattern and practice suits" brought by the Attorney General.

\section{TitLe VII AND SECTION 1982}

\section{Coverage}

While there is, to be sure, a considerable duplication of coverage, section 1981 and Title VII differ substantially in their methods of enforcement and scope of application. In seeking to implement the common objective of eliminating discrimination in employment, each act reaches areas not affected by the other. Thus, protection against employment discrimination under Title VII extends not only to black people but to those individuals who may be denied employment because they are, for example, Puerto Rican, American-Indian, Jewish, persons of Italian or Eastern European ancestry, or members of the fairer sex. ${ }^{48}$

In addition, the Title makes the indication of any discriminatory preference in advertising an unlawful employment practice. Moreover, the EEOC and the Attorney General are permitted to take positive action to eliminate employment discrimination. ${ }^{47}$ Thus, a major advantage of Title VII over section 1981 is that the Attorney General has the power under the former to initiate suits on his own or to intervene in private civil actions to help bring about compliance with the Act. ${ }^{48}$ On the other hand, section 1981 has several apparent advantages over Title VII. First, the expensive, time-consuming procedural steps before the EEOC and state fair-employment commissions, necessary under Title VII, would not be required in a section 1981 action..$^{49}$ Second, under Title VII, employers, unions, and employment agencies are the only parties against whom an action can be brought; under section 1981 it would be possible to expand the scope of liability to include others who may interfere with the right "to make and enforce contracts." 50 Third, while the 1964 Act exempts federal, state, and local governments, government corporations, and private membership clubs from compliance with its

46. Compare id. $\S 2000$ with id. $\S 1981$.

47. Id. $\$ \S 2000 \mathrm{e}-5(\mathrm{a}),(\mathrm{e}),-6(\mathrm{a})$.

48. Id. $\$ \S 2000 \mathrm{e}-5(\mathrm{e}),-6(\mathrm{a})$.

49. Under section 1981 the aggrieved party can seek relief directly from the courts. Id. $\S 1343(\mathrm{e})$.

50. Liability of municipalities under section 1981 may be possible. But see Monroc v. Pape, 365 U.S. 167 (1961), finding no such liahility under 42 U.S.C. $§ 1983$ (1964). 
provisions, ${ }^{51}$ section 1981 is not so limited. Fourth, section 1981 would not be limited to employers of twenty-five or more persons. Fifth, the extremely short statute of limitations effective under Title VII would not be controlling if the cause of action were based on section $1981 . .^{52}$ Finally, the remedial scope of a section 1981 action would be somewhat broader than that of Title VII; in addition to injunctive relief, reinstatement, and an award of back pay under the 1964 Act, there would be the possibility of exemplary damages in an appropriate section 1981 situation..$^{53}$

Although Title VII's procedures have not been as cumbersome and lengthy as some predicted and although, with minor exceptions, the courts have adopted a relatively permissive attitude toward Title VII's formal requirements, holding most of the limitations in the statute to be "directory" rather than "mandatory," 54 meaningful and effective relief under the Act is still a long process. ${ }^{55}$

51. 42 U.S.C. $\S 2000 \mathrm{a}(\mathrm{e})(1964)$.

52. Section 1981 provides no limitation period. In the absence of any express period, under companion section 1983 courts have held that the period provided by the state statute for similar actions applies. See O'Sullivan v. Felix, 233 U.S. 318 (1914); Crawford v. Zeitler, 326 F.2d 119 (6th Cir. 1964); Horn v. Bailie, 309 F.2d 167 (9th Cir. 1962). Cf. Weiser v. Schwartz, 286 F. Supp. 389 (E.D. La. 1968), where it was held that federal law determines when the limitation period begins to run. Moreover, in Jones the Court recognized, as support for allowing use of section 1982, that if the statute of limitations of Title VIIl applied-180 days-the case would have had to be dismissed. 392 U.S. at 417-18 n. 21 .

53. See Sullivan v. Little Hunting Park, Inc., 396 U.S. 229 (1969). In that case the court held that "[ $t]$ he existence of a statutory right implies the existence of all necessary and appropriate remedies," $i d$. at 239, even if the statute provides no explicit method of enforcement. The Court noted that 28 U.S.C. § 1343(4) (1964), "created federal jurisdiction for "damages or . . equitable or other relief under any Act of Congress providing for the protection of civil rights. . . " 396 U.S. at 238. Compensatory damages for the deprivation of a federal right are governed by federal standards. 42 U.S.C. $§ 1988$ (1964) provides:

The jurisdiction in civil . . matters conferred on the district courts by the provisions of this chapter . . . for the protection of all persons in the United States in their civil rights, and for their vindication, shall be exercised and enforced in conformity with the laws of the United States, so far as such laws are suitable to carry the same into effect; but in all cases where they are not adapted to the object, or are deficient in the provisions necessary to furnish suitable remedies and punish offenses against law, the common law, as modified and changed by the constitution and statutes of the State wherein the court having jurisdiction of such civil or criminal cause is held, so far as the same is not inconsistent with the Constitution and laws of the United States, shall be extended to and govern the said courts in the trial and disposition of the cause.

As the Court read section 1988, either federal or state rules on damages may be utilized, dcpending on which better serves the policies expressed in the federal statutes. It has also been suggested that damages may be available under Title VII. See, e.g., 396 U.S. at 240. See Note, Tort Remedies for Employment Discrimination Under Title VII, 54 VA. L. REv. 491 (1968).

54. See Colcman, supra note 43 , at 29-31.

55. Id. 


\section{Applicability of Section 1981}

It has been suggested that the detailed and comprehensive nature of Title VII compels adherence to the procedure outlined by Congress and that any conflict between Title VII and section 1981 must be resolved in favor of the former.$^{56}$ Reference to the Supreme Court's opinion in Jones is heIpful in determining the validity of this contention. In that case, the Court was faced with the problem of reconciling section 1982 with the Fair Housing Title of the Civil Rights Act of 1968. The Court emphasized that section 1982 is not a comprehensive open-housing law but deals only with racial discrimination and does not address itself to discrimination on grounds of religion or national origin. ${ }^{57}$ Aftcr enumerating the areas which section 1982 does not cover and emphasizing that the section contains none of the exemptions that Congress included in the Civil Rights Act of 1968, the Court concluded that it would "be a serious mistake to suppose that $\S 19.82$ in any way diminishes the significance of [the Fair Housing Title of the 1968 Act]." ${ }^{58}$ With section 1981 like section 1982, applying only to racial discrimination and with the employment title of the 1964 Act containing exemptions not included in the Civil Rights Act of 1866, it may be argued that Title VII does not diminish the significance of section 1981.

In the Jones opinion the Court further noted that Congress was aware that Jones was pending before the Court and therefore foresaw the significance of the eventual result. Yet, the 1968 Act does not mention section $1982 . .^{59}$ The Court thus concluded that it could not assume a congressional intention to effect any proccdural or substantive change in the earlier statute. ${ }^{60}$ Moreover, said the Court, the Fair Housing Title of the 1968 Act contains a "savings" clause which indicates that it was not intended to affect any other available remedy - state or federal. ${ }^{\text {.1 }}$

56. Harrison v. American Can Co., 2 F.E.P. Cases 1 (S.D. Ala. 1969).

57. Compare 392 U.S. at 412 with 42 U.S.C. $\S \S 3604-06$ (Supp. V 1970).

58. 392 U.S. at 415.

59. Id.

60. Id. at 416-17, n.20.

61. Id. at 417. The Savings clause reads:

Nothing in this title shall be construed to invalidate or limit any law of a state or political subdivision of a state, or of any other jurisdiction in which this title shall be effective, that grants, guarantees, or protects the same rights as are granted by this title; but any law of a state, a political subdivision, or other such jurisdiction that purports to require or permit any action that would be a discriminatory housing practice under this title shall to that extent be invalid. 42 U.S.C. $\$ 3615$ (Supp. V 1970). 
Although helpful by analogy, Jones does not resolve the problem of the conflict between Title VII of the 1964 Act and section 1981, for the situation in Jones has been distinguished by at least two courts. In Waters $v$. Wisconsin Steel Works, ${ }^{62}$ the court suggested that section 1982 was unaffected by the enactment of Title VII of the Civil Rights Act of 1964 because that Title contains a clause saving prior legislation. Moreover, it was contended in Harrison v. American Can Co. ${ }^{63}$ that while Congress knew of the pendency of Jones in 1968, it still enacted Title VII of the 1968 Act and declared in the savings clause that no limitation on any other law applicable to discrimination in housing was intended. Both cases imply that the lack of a similar savings clause in Title VII of the 1964 Act somehow weighs against the applicability of section 1981. This seems an erroneous suggestion for, as the Harrison opinion admits, ${ }^{64}$ Congress in 1964 could not forecast the judicial resurrection of the early Civil Rights Act from oblivion four years later. Furthermore, both Congress and the nation believed that in enacting Title VII in 1964, employment discrimination by private parties was being placed under federal statutory coverage for the first time ${ }^{65}$ Obviously, the presence or absence of a savings clause in Title VII, written in 1964, when Congress was unaware that a section 1981 cause of action existed, can have no bearing on the issue of congressional intent with regard to section 1981.

\section{Procedural Requirements}

A more serious question concerns the extent to which the procedural requirements of Title VII restrict the viability of section 1981. In Harrison, the district court held that an aggrieved person must pursue the lengthy procedure outlined in the 1964 Act before the possibility of using section 1981 could be considered; to do anything else, reasoned the court, would "in essence ... declare a major congressional enactment to have been an idle and unnecessary gesture ....".

However, in the more recent case of Waters v. Wisconsin Steel Works, ${ }^{67}$ the Court of Appeals for the Seventh Circuit faced the

62. 427 F.2d 476 (7th Cir. 1970).

63. 2 F.E.P. Cases I (S.D. Ala. 1969).

64. Id. at 3.

65. See, e.g., Vass, supra note 37.

66. 2 F.E.P. Cases at 3.

67. 427 F.2d 476 (7th Cir. 1970). 
conflict of section 1981 and Title VII head-on and developed what might be termed a compromise solution. In an effort to reconcile the two measures, the court held that section 1981 could be utilized but that a plaintiff must first exhaust his Title VII administrative remedies or provide a reasonable excuse for his failure to do so. Whether an explanation is reasonable should be determined on a caseby-case basis. ${ }^{88}$ Thus, in Waters, the plaintiffs were permitted to sue a. labor union under section 1981 even though the union could not have been sued under Title VII because the plaintiffs had failed to charge the organization before the EEOC. The failure to follow Title V1l procedure was alleged to have bcen caused by the plaintiffs' lack of knowledge of the union's complicity in company discrimination until the short statute of limitations for bringing a Title VII action had run. ${ }^{69}$

The defendants in Waters argued that the uniform and comprehensive nature of Title VII strongly implied that Congress intended the Act to be the sole vehicle for the attack on employment discrimination and that pre-existing rights, such as those derived from section I98I, were thus abolished. Dismissing this argument, the Waters court concluded that the proper question, for purposes of determining whether rights under section 1981 were repealed by implication, should be: Does the legislative history demonstrate that Congress would have intended repeal if it had been aware of the preexisting rights available under the Civil Rights Act of $1866 ?^{70}$ The court surmised that, despite some indications to the contrary, Congress would have modified the right of action under section 1981 if it had been cognizant of the early statute's existence and vitality. Judge Swygert, speaking for the court, emphasized the procedural framework of Title VII as a strong indication of congressional preference for conciliation of disputes without resort to litigation. ${ }^{\text {" }}$

Although the Waters court presents a cogent argument for retracting the scope of a section 1981 right when there is a conflict with the conciliation procedures of Title VII, the court possibly proceeded from an erroneous initial assumption. As the court stated it, the question was whether Congress would have repealed section 1981 had it been aware of that statute's implications. It might be

\footnotetext{
68. Id. at 485 .

69. Id. at 487, n. 20 .

70. Id. at 485 .

71. Id. at 486.
} 
contended that the proper inquiry should be whether, and in what form, Congress would have enacted Title VII. The enactment of Title VII was the culmination of many years of strenuous efforts by civil rights forces, both within Congress and without. Indeed, while discrimination because of sex, religion, and national origin falls within the purview of Title VII, the elimination of discrimination on account of race was unquestionably the primary motivation behind its enactment. Congressional civil rights advocates, who had fought a long battle to enact legislation to ameliorate the condition of the black working man, would not likely surrender such a potentially potent weapon as section 1981 in exchange for Title VIl, whose broader scope is more than offset by its complicated procedure and almost total lack of enforcement provisions. Had Congress been aware of the existence of a section 1981 action, necessary votes could probably not have been mustered to repeal or modify that statute. Recognizing the improbability of repeal, it seems more plausible that congressional forces which had favored conciliation over litigation would have actively advocated the passage of Title VII as a supplement to section 1981, thus salvaging, at least to some extent, the conciliation approacl to resolving employment discrimination disputes.

The Supreme Court's recent decision in Sullivan v. Little Hunting Park, Inc. ${ }^{72}$ sheds additional light on the resolution of the conflict between section 1981 and Title VII. In that case the Court, citing Jones, held that the "hierarchy of administrative machinery" provided by the public accommodations provisions of Title VI of the 1964 Civil Rights Act "is not at war with survival of the principles embodied in $\S 1982 . " 73$ The same comment can be made about Title V11 and section 1981. Both Title VII of the 1964 Act and Title VI of the same Act, litigated in Sullivan, contain similar procedures which must be followed before an aggrieved party may contest discriminatory practices in court. ${ }^{74}$ It seems likely that if the "administrative machinery provided by Title VI is not at war with survival of . . . $\$ 1982$," the similar mechanism of Title VIl can coexist with section 1981.

Moreover, Congress evidently did not see conciliation as necessarily predominant on a heirarchy of appropriate methods of

72. 396 U.S. 229 (1970).

73. Id. at 237.

74. Compare id. with 42 U.S.C. $§ 2000 d-1$ (1964). 
enforcing equal opportunity in employment. For example, Congress rejected by a more than two-to-one margin Senator Tower's amendment that would have made Title VII the exclusive remedy for employment discrimination. ${ }^{75}$ Accordingly, courts have held that Title VII does not preempt National Labor. Relations Board jurisdiction to hear charges of unfair labor practices based on the union's duty of fair representation. ${ }^{76}$ In addition, Congress provided in another section of Title VIl for the imposition of appropriate state criminal sanctions as a possible initial step against discriminators. ${ }^{77}$ In providing for the enforcement of state fair-employment practices laws in Title VII, Congress seemingly intended to encourage the utilization of all weapons at the disposal of injured parties to aid the fight against employment discrimination. ${ }^{78}$ Allowing section 1981 to be used to fight employment discrimination as a complement to Title VII gives full expression to this congressional intent.

\section{ConCLUSION}

Although Congress did, indeed, express a preference for conciliation over litigation in Title VII, this preference falls far short of meeting the stringent repeal by implication requirements set down by the Supreme Court in cases where two statutes conflict. The Court has held that when there are two acts upon the same subject, the rule is to give effect to both if possible. "[I]t is not sufficient to establish that subsequent laws cover some or even all of the cases provided for by [the prior act]; for they may be merely affirmative, or cumulative, or auxihary." 79 For repeal by implication, the Court requires "a positive repugnancy between the provisions of the new law, and those of the old; and even then the old law is repealed by implication only pro tanto to the extent of repugnancy." 80

It is apparent that the existence of two different pieces of legislation dealing in substantially different terms with employment

75. 110 CoNG. Rec. 13650-52 (1964).

76. E.g., Local 12, United Rubber Workers v. NLRB, 368 F.2d 12 (5th Cir. 1966), cert. denied, 389 U.S. 837 (1967).

77. 42 U.S.C. § $2000 \mathrm{e}-5$ (c) (1964).

78. The Nixon administration has attempted to provide supplemental remedies to Title VII to remove racially discriminatory employment practices. See 38 U.S.L.W. 2191 (Op. Att. Gen., Sept. 22, 1969).

79. Wood v. United States, 41 U.S. (16 Pet.) 342, 362-63 (1842).

80. United States v. Borden Co., 308 U.S. 188, 198-99 (1939). See also Posados v. National City Bank, 296 U.S. 497, 504 (1936). 
discrimination is not an ideal situation. It is also undeniable that some duplication of effort and confusion of obligations, rights, and remedies will occur. Obviously, comprehensive legislation carefully designed to eliminate inconsistencies, fill gaps, and clarify ambiguities would be the best approach for Congress to take in combating employment discrimination. Nevertheless, until such legislation is enacted, it would seem only reasonable to utilize all available vehicles, including both Title V11 and section 1981, to attack such discrimination. The most substantial obstacle to the utilization of section 1981 is its conflict with the administrative procedure of Title V11. The courts must carry the burden of resolving this conflict in light of congressional intent in enacting both pieces of legislation-the desire to eliminate racial discrimination and provide equal eniployment opportunities for all. It would be well to remember that in other areas where a strong desire to eliminate racial discrimination is evident, the Supreme Court has said that the Court has not merely the power but the duty to render a decree which will so far as possible eliminate the discriminatory effects of the past as well as bar like discrimination in the future. ${ }^{81}$

Recently the contention has been made that section 1981 was derived from section 16 of the Enforcement Act of 1870, rather than section 1 of the Civil Rights Act of $1866 .{ }^{82}$ The significance of this is that section 16 was enacted solely to insure that aliens would receive the equal protection of the laws guaranteed by the fourteentl amendment, and thus the "state action" limitation of the fourteenth amendment would bar the use of that section in private discrimination cases. Support for such a theory is found in the codifiers' historical note under section 1981 and in study of the congressional debates over section 16.83

81. Louisiana v. United States, 380 U.S. 145 (1965), invalidating interpretation and citizenship tests in voting. Accord, Gaston County v. United States, 395 U.S. 285 (1969), invalidating a discriminatory literacy test for voting.

82. See Cook v. The Advertiser Co., 39 U.S.L.W. 2413 (M.D. Ala. Jan. 15, 1971). But see Young v. International Tel. \& Tel. Co., 39 U.S.L.W. 2489 (3d Cir. Feb. 11, 1971); Boudreaux v. Baton Rouge Marine Contracting Co., _ F.2d - (5th Cir. 1971). The Supreme Court will have the opportunity to resolve this conflict as petition for certiorari has been filed in a private employment discrimination case involving section 1981. Dobbs House, Inc. v. Sanders, 431 F.2d 1097 (5th Cir. 1970), petition for cert. filed, 39 U.S.L.W. 2413 (U.S. Feb. 3, 197I) (No. 1079).

83. See, e.g.. Cong. Globe, 4 Ist Cong., $2 \mathrm{~d}$ Sess. 3871 (1870). 
If it is concluded that section 1981 was derived from the 1870 Act, what is the status of that portion of the 1866 Act from which section 16 was derived? In 1874 the United States Statutes at Large were codified. Because the codifiers were required to include in the Revised Statutes those acts which were "general and permanent in nature," 1866 Act, it seems likely that the omission of part of the 1866 Act was an error in codification. ${ }^{85} \mathrm{~A}$ possible explanation for the codifiers' error is that they were confronted with two almost identical statutes, section 1 of the 1866 Act and section 16 of the 1870 Act. On its face section 16 appears to be slightly broader, as its coverage extends to "all persons" rather than only to "citizens," and thus the codifiers might have reasoned that by including in the codification what appeared to be the broader provision, the inclusion of the almost identical provisions of the 1866 Act would be superfluous. ${ }^{88}$ Thus, section 1981 seems to have been read by the courts as if both the pertinent portion of the 1866 Act and section 16 of the 1870 Act were subsumed therein. ${ }^{87}$ Such a dual interpretation of section 1981 gives force to the intent of Congress that the Revised Statutes should include "all statutes . . . general and permanent in their nature." 88

84. Act of June 27, 1866, ch. 140, 14 Stat. 74.

85. Furthermore, it seems absurd to contend that such a controversial piece of legislation would have been repealed without congressional comment.

86. Following this reasoning, the repealer contained in the Revised Statutes which expressly does not repeal acts "general and permanent in their nature" would not have repealed the pertinent section of the 1866 Act. Revised Statures ch. 74, $\$ 5596$ (1878).

87. Compare Hurd v. Hodge, 334 U.S. 24, 30-31 n.7 (1948), and United States v. Wong Kim Ark, 169 U.S. 649, 695-96 (1898) (which treat section 1981 as an reenaetment of section 16 of the 1870 Act), with Jones v. Alfred H. Mayer Co., 392 U.S. 409, $441-43$ n.78 (1968) (which considers section 1981 to be derived from the $1866 \mathrm{Act}$ ).

88. Act of June 27, 1866, ch. 140, 14 Stat. 74. 